ВАСИЛЬЕВ Игорь Владимирович - кандидат технических наук, военнослужащий (Россия, 2. Москва; vasigo74@yandex.ru)

КУЗНЕЦОВ Андрей Николаевич - аспирант Российской академии народного хозяйства и государственной службы при Президенте РФ (119571, Россия, г. Москва, пр-кт Вернадского, 82, стр. 1; Lampa.kuz@mail.ru)

\title{
ИСТОРИЧЕСКАЯ ПАМЯТЬ КАК ФАКТОР ПАТРИОТИЧЕСКОГО ВОСПИТАНИЯ ГРАЖДАН
}

\begin{abstract}
Аннотация. Статья обосновывает важность сохранения исторической памяти и исторической правды о роли России в мировом цивилизационном процессе. Авторы на конкретных примерах показывают нарастающую опасность политического использования истории Второй мировой войны и Великой Отечественной войны 1941-1945 гг. советского народа против фашистской Германии в ущерб исторической правде; описывают генезис понятия «историческая политика». В статье показана роль и значение исторической памяти и исторической правды в патриотическом воспитании граждан; раскрыты новые тенденции в политике, направленные на размывание и стирание в сознании людей исторической памяти ради корпоративных целей и интересов; высказан ряд предложений, направленных на сохранение исторической памяти как фактора патриотического воспитания граждан Российской Федерации.

Ключевые слова: историческая память, историческая правда, историческая политика, безопасность, символическая политика, патриотизм, патриотическое воспитание, культура, культурная политика, информационная война
\end{abstract}

$\mathrm{B}_{\mathrm{a}}^{\mathrm{a}}$ ажность исторической памяти народа обусловлена тем, что она выступает своеобразным пантеоном национальной идентичности: содержит знания об исторических битвах, о судьбоносных событиях, жизни и творческой деятельности выдающихся деятелей политики и науки, культуры и искусства; воспроизводит непрерывность и преемственность социального бытия. Вся история человечества - это банк памяти. Историческая память выступает в роли посредника в смене поколений: добытые в прошлом знания становятся необходимым элементом в будущем для дальнейшего развития культуры, в которой всегда присутствует историческая основа и историческая преемственность.

Д.С.Лихачев утверждал, что «память противостоит уничтожающей силе времени. Память - преодоление времени, преодоление пространства. Память основа совести, нравственности, память - основа культуры. Хранить память и беречь память - это наш нравственный долг перед самим собой и перед потомками. Память - наше богатство» [Соломатина, Аргунов 2013: 190-196].

«Кто управляет прошлым, тот управляет будущим. Кто управляет настоящим, управляет прошлым». Эта формула Дж. Оруэлла из его известной антиутопии «1984», с одной стороны, предостерегает, что существует реальная возможность посредством политики воздействовать на историю (на прошлое), но, с другой стороны, она же заставляет помнить и о том, что современные субъекты политики могут по-своему трактовать предшествующую им историю (прошлое). И в этой связи бурные споры совсем еще недавнего времени относительно преподавания истории, сохранения исторических памятников, отношения к историческим деятелям не столь давнего прошлого, оценки содержания художественных произведений, затрагивающих исторические события, стилистики празднования знаменательных и памятных дат не являются случайными. И одна из главных причин развернутых споров и действий в направлении забвения истории и исторической правды была в том, что некоторым политическим субъектам очень хотелось «скорректировать» историческую память граждан, 
затормозить процессы развития и консолидации общества на старых патриотических ценностях, формирования культурной и гражданской идентичности его членов на традициях предшествующих поколений. «Без памяти не может быть ни человека, ни социальной группы, ни государства. А согласие по поводу памяти прошлого - центральный, ключевой момент формирования идентичности: социальной, национальной, культурной» [Тульчинский 2018: 222].

Активное обсуждение проблем политического использования исторической памяти, самой истории стало предметом интересов широкого круга ученых [Малинова 2012; Поцелуев 2012].

Термин «историческая политика» возник в 80-е гг. XX столетия в Германии - в критике левыми попыток канцлера Г. Коля подвергнуть ревизии германское «покаяние» за Вторую мировую войну и стал распространяться в политологических исследованиях ${ }^{1}$. В 2004 г. это понятие стало эксплуатироваться поляками для оправдания использования истории в решении своих политических проблем. Эти проблемы возникли в связи с вступлением в НАТО и ЕС посткоммунистических государств Восточной Европы, которое взорвало существовавший длительное время в Западной Европе консенсус по общей исторической памяти. В этот консенсус входило безоговорочное осуждение холокоста. Однако в новом национальном сознании новых членов НАТО и ЕС фигурирует борьба с советским империализмом, в т.ч. в виде сотрудничества с нацистами. В результате в Европе появились «хорошие» и «плохие» фашисты.

Этот пример показывает важность исторической памяти, необходимость ответственного осмысления ее роли и динамики. Эту важность трудно переоценить в деятельности по патриотическому воспитанию граждан в условиях развернувшейся с конца 80-х гг. XX столетия тотальной информационной войны против России, ее народа. Эта война ведется в соответствии с американской доктриной А. Даллеса и направлена на умаление роли и значения России, русского народа в общем цивилизационном развитии человечества.

Частным выражением этой тотальной войны выступает манипулирование историей Второй мировой войны, подчинение исторической науки политической конъюнктуре.

Сегодня в истории Второй мировой войны мы видим резкое обострение трактовок причин и ответственности за развязывание войны. Ответственность за эрозию исторического нарратива несут страны Запада, в первую очередь страны Восточной Европы [Лапшин 2020: 9].

Намерения и действия ряда стран Западной и Восточной Европы, а также Соединенных Штатов Америки по искажению истории Второй мировой войны преследуют далеко идущие цели - посеять в сознании граждан России неверие в величие российской державы, в ее духовную, материальную и моральную мощь, в ее заслуги перед человечеством в разгроме фашистской Германии, в разоблачении самой идеологии фашизма.

В информационной войне патриотизм открыто не отвергается. Формы и методы борьбы с российским патриотизмом стали сегодня более изощренными и утонченными. Понятие «патриотизм» деформируется, принижается и извращается его истинная сущность не только в СМИ, рекламе, моде, но и в политике, культуре, образовании, науке. Патриотизм нередко смешивают с самыми различными понятиями и явлениями, такими как национализм, антисемитизм, маргинальность, регионализм, социальный консенсус, социальная

\footnotetext{
${ }^{1}$ Миллер А.И. 2015. Кто взорвал консенсус истории и чем за это заплатит. О европейских войнах памяти и роли России, которая активно в них участвует. - Новая газета. № 38. 4 июня. С. 2-3.
} 
солидарность, толерантность, экстремизм и даже фашизм [Лутовинов 2015: 60].

В результате информационной войны появился феномен лжепатриотизма, множатся ряды псевдопатриотов, использующих деформированное понятие патриотизма в своих корыстных целях, корпоративных, а порой и преступных интересах. Многочисленные вариации извращения сути патриотизма осуществляются при поддержке ряда зарубежных гуманитарных фондов, благотворительных организаций, зачастую финансируемых из государственных бюджетов. Российское информационное пространство наполняется дезинформацией, подрывающей веру граждан в силу государства, устои морали и нравственности, верность выбранного Россией пути развития. Особую активность в информационных кампаниях проявляют США, страны Балтии, Польша, Грузия, Румыния, Украина. В этих странах политическое манипулирование историей возведено в ранг государственной политики.

В современной зарубежной политической риторике и исторической публицистике просматривается стремление некоторых политических элит пересмотреть итоги Второй мировой войны и Великой Отечественной войны советского народа против немецко-фашистских захватчиков. Президент России В.В. Путин характеризует подобную тенденцию как «злобные выпады» против исторической правды.

С точки зрения научной истории превращать Россию из победителя во Второй мировой войне в агрессора могут только люди, которые явно находятся не в ладах со своей совестью и имеют свои корыстные интересы. Как страна-победительница Россия играла ведущую роль в становлении действующего ныне миропорядка. Но кому-то не нравится роль России в современной системе международных отношений.

Современная многополярная система мироустройства регулярно сталкивается с претензиями США и ведущих государств Западной Европы на мировое господство, которые в т.ч. подкреплены «историческими исследованиями» антироссийской направленности. Эта историческая мифология целенаправленно создавалась десятилетиями. Она же стала причиной пересмотра причин начала войны, ее характера и результатов.

Сегодня в России многое делается для сохранения исторической памяти и воспитания населения в духе патриотизма на исторической правде. Огромную роль в патриотическом воспитании граждан играет Всероссийский организационный комитет «Победа» при Президенте РФ. Он образован в целях проведения единой государственной политики в области патриотического воспитания граждан и в отношении ветеранов.

Выступая на заседании Всероссийского оргкомитета «Победа» в декабре 2019 г. В.В. Путин отметил важность сохранения исторической памяти как важнейшего компонента системы патриотического воспитания населения. В частности, им было сказано: «Особое внимание - работе, связанной с сохранением памяти о Великой Отечественной войне и о ее героях. Говорю об обновлении музейных экспозиций и проведении специальных выставок, акций, научнопрактических конференций, в том числе о системном введении в научный оборот архивных документов, о том, чтобы они были доступны для граждан, в том числе с помощью современных цифровых технологий и информационных платформ» 1 .

Президент также обратил внимание органов власти на местах на необходимость постоянного контроля вопросов благоустройства воинских мемориа-

1 http://www.kremlin.ru/events/president/news/62293 (проверено 30.04.2021). 
лов, неукоснительного соблюдения установленных законодательством норм обследования и постановки на учет вновь выявляемых братских захоронений. Одним из приоритетов в патриотическом воспитании граждан должна стать поддержка общественных инициатив, содействие поисковым и волонтерским объединениям граждан, краеведам, просто энтузиастам; людям, которые увлекаются историей и отдают этому увлечению свою душу, время, годы своей жизни, - всем, кто не лозунгами, а делом занимается патриотическим воспитанием молодежи, помогает подросткам, детям впитать ценности любви к Отечеству, понять, что значит Родина для человека и гражданина и почему нужно ее беречь. В основу просветительской работы следует положить личный пример, искренние поступки и значимые, достойные и понятные всем результаты.

Данные рекомендации президента РФ будут положены в основу новой программы «Патриотическое воспитание граждан Российской Федерации до 2025 года».

В современном мире усиливаются попытки искажения истории и исторической правды, воздействия на историческую память россиян посредством методик и технологий символической политики ${ }^{1}$. В ряде европейских стран развернулась борьба с памятниками советским гражданам, погибшим в борьбе с нацизмом. Лидирует в антироссийской гонке Польша, где только за 2016 г. снесено 30 монументов, символизирующих освободительную миссию Красной армии и советско-польское братство ${ }^{2}$.

Акты надругательства и вандализма над памятниками постоянно совершаются на Украине. Такие же факты имеют место в Германии, Чехии, Венгрии, Австрии, Эстонии, Латвии и других странах.

Одна из резолюций 2019 г. Европейского парламента поставила фактически на одну доску и нацистских агрессоров, и Советский Союз. СССР пытаются обвинить в развязывании Второй мировой войны, забывая о том, кто напал на Польшу 1 сентября 1939 г. и на Советский Союз 22 июня 1941 г.

Для воспитания исторического сознания, патриотизма и гражданственности сегодня в ряде регионов используются разнообразные формы, позволяющие охватить широкий спектр интересов граждан. Наиболее эффективны военноисторические и военно-патриотические формы деятельности, использование метода исторической реконструкции, а также привлекательные досуговые, образовательные и просветительские формы, которые могут использоваться как на уровне неформальных объединений граждан, так и в форме культурной, творческой и проектной деятельности. Например, в Перми для изучения вопросов военной тактики XX в., воспитания слаженности подразделений

\footnotetext{
1 С помощью современных СМИ фактом становится не то, что произошло, а то, что рассказали. Таким образом, общественное мнение формируется на конструируемых (абстрактных) фактах. Эта политика предполагает эффективное использование символических ресурсов. По заказу правящих элит формируются восприятие и понимание реальности, истории, ожидания, надежды, настроения, запросы граждан. Символическая политика использует не столько прямое властное принуждение или подкуп, сколько влияние, основанное на привлекательности предлагаемых ценностей, норм, стереотипов. Любые феномены социальной реальности могут выступать предметами, инструментами символической политики (события, тексты, изображения, личности, природные объекты и катаклизмы, артефакты культуры и т.д.) при условии, если они становятся предметом публичного дискурса и связаны с решением проблем сегодняшнего дня. Пропагандистские практики идут по пути прямой дезинформации, а не по пути информации и ее интерпретации. Как результат, информационное общество мутирует в дезинформационное общество.

2 www.kremlin.ru/events/president/news/51641 (проверено 30.04.2021).
} 
используются такие формы, как страйкбол, метод исторической реконструкции, где достигается комплексный эффект: изучение истории, тактики, вооружения, выработка прикладных навыков, освоение старинных технологий, ремесел, повседневной культуры и быта ${ }^{1}$.

Развивать историко-просветительскую и историко-культурную деятельность можно, опираясь на сложившиеся формы патриотического воспитания, постепенно укрепляя их новым контентом, расширяя возможности для дальнейших перспектив. Однако развитие историко-культурной деятельности требует создания новых музейно-туристических комплексов, финансовых затрат. Но, как показывает практика, музейно-туристические комплексы не только компенсируют затраты и способствуют массовой пропаганде отечественной истории и культурного наследия, но и способствуют развитию отечественного туризма. Богатое историческое наследие России позволяет создать сотни исторических клубов, музейно-туристических комплексов, патриотических объединений, которые будут опорой в реализации системных культурных программ на федеральном, региональном и муниципальном уровнях.

Не в полной мере задействован потенциал ветеранов Великой Отечественной войны, ветеранов боевых действий, ветеранских объединений в целом. По состоянию на 1 ноября 2019 г. на территории России проживают 60842 участника Великой Отечественной войны, 1089 тыс. участников боевых действий, приравненных к инвалидам Отечественной войны. На уровне муниципальных образований их знают; при должном организационном и методическом руководстве они могли бы стать не только активными пропагандистами исторической правды о Великой Отечественной войне, но и главными субъектами патриотического воспитания подрастающего поколения.

Нам представляется, что Российский союз молодежи как одна из самых массовых молодежных неполитических некоммерческих организаций России мог бы активнее проявить себя в работе с ветеранами в организационном аспекте. Воспитание гражданственности и патриотизма - одна из приоритетных уставных обязанностей Российского союза молодежи.

Многоплановая работа государства по патриотическому воспитанию, сохранению исторической памяти граждан должна постепенно и последовательно передаваться в руки общества. Сложилось такое положение, что сегодня органы исполнительной власти во главе с Министерством обороны России и Министерством иностранных дел России несут на своих плечах львиную долю труда по сохранению исторической памяти о Великой Отечественной и Второй мировой войне. Под организационным и методическим руководством данных органов исполнительной власти в стране и за рубежом проведены и проводятся десятки патриотических акций.

Так, например, Министерство обороны проводит многоплановую работу по сохранению исторических традиций, увековечению памяти погибших героев и борьбе с фальсификацией истории. В нашей стране имеется 31078 воинских захоронений, где предано земле более 4,4 млн человек. Более 12 тыс. воинских захоронений находятся за пределами РФ, в 56 государствах. В них захоронены более 4,12 млн погибших воинов. За последние годы проведена паспортизация 1792 воинских захоронений, проведены реставрационные работы на 1652 мемориальных объектах, увековечены на мемориальных плитах более 19 тыс. погибших защитников Отечества.

Смещение центра деятельности по воспитанию исторической памяти в

1 Шуваев Ю.А. 2018. Историческая память как основа патриотического воспитания. Доступ: https://yandex.ru/turbo/oboznik.ru/h/?pcgi=p\%3D42755 (проверено 30.04.2021). 
сознании граждан от исполнительной власти к гражданскому обществу повысит эффективность всей системы патриотического воспитания, т.к. граждане будут сами активными субъектами воспитания. Это смещение позволит привлечь в полной мере ресурсы гражданского общества к решению общенациональных проблем, в частности к развитию гражданственности и патриотизма.

В России около 500 общественных объединений граждан ${ }^{1}$. Многие из них имеют гражданскую, патриотическую направленность. Но проблема заключается в том, что большинство из них нацелены на решение узких корпоративных задач. В уставах общественных объединений, по большому счету, недостает гражданственности и ориентированности на развитие российского патриотизма, решение приоритетных национальных проблем. Мы не агитируем за политизацию общественных объединений граждан, а выступаем за гражданскую позицию и за корпоративизацию общественных объединений.

Министерству юстиции, видимо, следует обратить внимание на структуризацию общественных объединений, придать им вертикальную иерархию по примеру вертикали власти в РФ. Такая структуризация могла бы позволить создать методическое и организационное сопровождение деятельности неполитических объединений граждан федеральным центром (по образцу профессиональных союзов граждан).

Больше всего в таком структурном построении нуждается многочисленная сеть ветеранских и детско-юношеских объединений. Мы не призываем создавать министерство по делам ветеранов, как это сделано, например, в США. Но, если мы ждем эффективности в деятельности ветеранских объединений, то прежде всего необходимо иметь центр по их организационному построению и методическому сопровождению активной деятельности ветеранских объединений.

\section{Список литературы}

Лапшин А.О. 2020. К осмыслению истории вчера и сегодня. - Власть Т. 28. № 2. C. 9-14.

Лутовинов В.И. 2015. Основы информационного обеспечения патриотического воспитания молодежи. - Информационное сопровождение в сфере патриотического воспитания граждан Приволжсккого федерального округа: опыт, перспективы, сотрудничество: материалы межрегиональной научно-практической конференции. Пермь, 26 ноября 2015 г. (под общ. ред. В.И. Лутовинова), Пермь.

Малинова О.Ю. 2012. Символическая политика: контуры проблемного поля. - Символическая политика: сборник научных трудов. М.: Изд-во ИНИОН РАН. C. 5-16.

Поцелуев С.П. 2012. «Символическая политика»: к истории концепта. Символическая политика: сборник научных трудов. М.: Изд-во ИНИОН РАН. C. 17-53.

Соломатина В.В., Аргунов В.Г. 2013. Историческая память народа. - Научное сообщество студентов XXI столетия. Общественные науки: материалы XI студенческой международной заочной научно-практической конференции. Новосибирск, 21 мая 2013 г. Новосибирск: СибАК. С. 190-196.

Тульчинский Г.Л. 2018. Политическая культура России: источники, уроки, перспективы. СПб: Алетейя. 294 с.

\footnotetext{
1 minjust.ru/spisok-obshestvennyh-obedineniy (проверено 24.03.2020).
} 
VASIL'EV Igor' Vladimirovich, Cand.Sci. (Tech.Sci.), serviceman (Russia, Moscow, vasigo74@yandex.ru) KUZNETSOV Andrey Nikolaevich, postgraduate student of the Russian Presidential Academy of National Economy and Public Administration (RANEPA) (bld. 1, 82 Vernadskogo Ave, Moscow, Russia, 119571; Lampa.kuz@mail.ru)

\title{
HISTORICAL MEMORY AS A FACTOR OF PATRIOTIC EDUCATION OF CITIZENS
}

\begin{abstract}
The article substantiates the importance of preserving historical memory and historical truth about the role of Russia in the world civilizational process. The authors give the concrete examples to show the growing danger of political use of the history of the Second World War and the Great Patriotic War of 1941-1945 of the Soviet people against Nazi Germany to the detriment of historical truth. The article describes the genesis of the concept of historical policy; shows the role and significance of historical memory and historical truth in the patriotic education of citizens; reveals new trends in politics aimed at blurring and erasing historical memory in the minds of people for the sake of corporate goals and interests. The authors make a number of proposals aimed at preserving historical memory as a factor of patriotic education of citizens of the Russian Federation.
\end{abstract}

Keywords: historical memory, historical truth, historical policy, security, symbolic policy, patriotism, patriotic education, culture, cultural policy, infowar 